\title{
INTERNALISATION OF HUMANE VALUES AMONG CHILDREN OF EARLY CHILDHOOD AND LATER CHILDHOOD FOR INTEGRATED SOCIAL AND MORAL DEVELOPMENT
}

KEY WORDS: Values

Education, Value Inculcation

\section{Madhurima} Mukherjee

\author{
Faculty, Department of Education Dumdum Motijheel College
}

Education is only complete when it leads to all round development of a child, which encompasses not only psychological but also moral and social development. This moral and social development is based on virtues which helps one to choose the right path in life. Basically values steer one's life's journey These are the standards or guidelines for an individual's life. Values are modes of organising conduct Values poses both the cognitive and affective dimensions. So, its importance as a building block of child's whole life is immense. Tender age is the right time for inculcating values for building better society. If values are integrated with Education system better result can be expected for getting a better integrated society

Values provide the general guidelines for the behaviour of the people. Today's child is the responsible citizen for future society. Tender age is the right time to inculcate values for the future responsible citizen. In the schooling age child is in mode of moulding because a child remains a clay model and through proper education he/she gets a shape .Not only from the formal education but informal education also plays an important role for shaping the behaviour and character for proper social and moral development of a child. Teaching of positive values are beneficial for the betterment of both individual and social life.

\section{CONCEPT AND IMPORTANCE OF VALUE EDUCATION AMONG CHILDREN :}

Values are basically the principles to guide us for the betterment of the quality of life. It forms the basic character of an individual and shapes the personality. Values encompasses within individual the do's and don'ts of behaviour. Being virtuous like being honest, having patience, expressing gratitude ,being respectful to everybody, having generosity ,being compassionate, forgiveness, humility, obedience, perseverance, being courageous moulds a life to the utmost betterment - one who sows VIRTUE reaps HONOUR .It is important to recall that values are priceless, while valuables are priced. (Goel and Goel ,2008).

Values regulate and guide human behaviour and action in our daily life. They are embedded in every word we select and speak, what we wear, ways in which we communicate, our perceptions and interpretation of others responses in what we say. They are constructed on the basis of interests, choices ,needs, desires and preferences. These comprise the nuclei of value formation. (Mondal , 2017). Values are the guiding principles of life which are conductive for all round development.Values involve the process of thinking , knowing ,understanding, feeling and action.

Tender age or school age is the age of moulding a life, giving a shaping, inculcating virtues, constructing personality, inculcating secular and democratic attire. This shaping of personality is important for individual's perspective to enable students to achieve personal fulfilment for success in life and work. As well as in societal perspective education aims to prepare the youth to contribute to society ,nation and for the world. Plato wrote in The Republic " The mark of an educated person is the willingness to use one's knowledge and skills to solve the problems of society ".the problem of declining values is multidimensional arising out of combination of major special forces such as globalisation, actualization , consumerism, commercialization , of education ,threats to humanity due to climatic changes, degradation of environment, violence and terrorism. These lead to insecurities, individualistic lifestyles, acceleration of desires
, misuse of science and technology, pessimisms , sense of alienation and other negative consequences (NCERT ,2000). Although erosion of values existed throughout .The history of human existence and is shared by all cultures but current degradation of values has become a matter of great concern in our country .(NCERT ,2000).

DEVELOPMENTS OF VALUE EDUCATION IN INDIA AFTER INDEPENDENCE：CONCERNS AND INITIATIVES OF VARIOUS EDUCATION COMMISSIONS AND COMIMITTEES :

\section{UNIVERSITY EDUCATION COMMISSION /RADHAKRISHNAN COMIMISSION, 1948 :-}

The first ever education commission after independence was Radhakrishnan Commission. This commission was much concerned about value inculcation among students. They were concerned about spiritual training and its importance "If we exclude spiritual training in our institutions, we would be untrue to our whole historical development ". The commission also marked the of education should be to develop character, to transmit of intellectual and ethical heritage of humanity to the young, to develop democratic values like liberty ,equality ,fraternity , social justice .The commission also said " to impart correct social vision is an essential aim of education .we do not work in social vaccum. Individual freedom entails social responsibility Radhakrishnan Commission recommended for doing SILENT PRAYER OR MEDITATION before the commencement of everyday school affairs . the commission also recommended reading of life stories and sayings of The Great peoples specifically from religion area like Jesus Chrtist , Buddhadev,Nanak , Ramanuj ,Kabir etc.

\section{- NATIONAL COIMIMISSION OF SECONDARY EDUCATION / MUDALIAR COMMISSION , 1952-53 :-} Mudaliar commission focused on the development of secular and national outlook among children of secondary stage Mudaliar commission also emphasised on CHARACTER BUILDING as the defining goal of education. Other than this discipline , cooperation , social sensitiveness ,perseverance should also be inculcated among school children .

\section{- INDIAN EDUCATION COIMMISSION /KOTHARI COIMIMISSION 1964-66 :-}

Kothari commission put the spotlight on EDUCATION AND NATIONAL DEVELOPMENT . Agreeing with the Sri Prakasha Committee Report ,1959 , it recommended direct moral instruction for which one or two periods a week should be set aside in the school time table.

NATIONAL POLICY ON EDUCATION , 1986 :-

NPE, 1986 advocated turning education into a forceful tool for 
the cultivation of social and moral values .Education should foster universal and eternal values ,oriented toward the unity and integrity of our people.

\section{- NPE-PROGRAIMME OF ACTION 1992 :-}

NPE-POA , 1992 tried to integrate the various components of value education into the curriculum at all stages of school education including the secondary stage.

\section{- THE NATIONAL CURRICULAR FRAMEWORI FOR SCHOOL EDUCATION ,2000:-}

According to NCERT ,2000 Education for values in school : A framework , "The very nature of value education implies empowering the students attitudes and skills as well as giving them the critical ability to use them in the contemporary everyday world , full of myriad challenges". It also says ," Education for values aims at promoting broader capabilities , attitudes and skills that matter not just in schools but also life beyond schools, making the world a better place for themselves and for their family, friends, collegues and others education for values highlights the understanding that values are tobe inculcated in students not just for their own interest but also for common good, reflecting the balance between individual's interest and larger interest .It advanced a plea to integrate value education into the curriculum.

\section{- NATIONAL CURRICULUM FRAMEWORK, 2005 : -}

NCF , 2005 articulates the need to reaffirm our commitment to the concept of equality amidst diversity ,mutual interdependence of human to promote values that foster peace, humaneness and tolerance in a multicultural society . The NCF,2005 particularly emphasizes education for peace as one of the national and global concerns.

\section{STRATEGIES OF VALUE INCULCATION AMONG} SCHOOL CHILDREN :

- Implanting values is different from teaching any other school subject (Hasan et.al. ,2014). Value not only covers the cognitive domain of a student but also covers the affective and psychomotor domain of the students. So inculcating values among students in depth not by force is a critical issue to assume. But small steps, some strategically taken initiatives, interactions, relations in different ways makes value internalise easier and sustainable in the long run.

- Some general strategies for value inculcation among school children can be-

\section{MEDITATION:-}

Meditation or silent prayer gives immense self-sense and calmness and peace filled mind. Meditation strengthens oneself ,builds self-confidence, enhances positive emotions, consolidates information received, concentration and assimilation, clear thinking and also helps to be in tune with oneself. In classroom situation, before starting teaching -learning procedure only two minutes could be spend for meditation -its like a warm up exercise especially for young children.

\section{VISUAL EXPERIENCES :-}

Learning through visual experiences such as symbols ,drawings ,charts , graphs , auditory and kinaesthetic experiences remains much more attractive to individuals These creates a powerful communication of attitudes and values and forming imaginary at the early primary years of schooling.

\section{ROLE PLAYING :-}

Role playing is used as a methodology for inculcating values. Role playing or acting out helps in better understanding and reinforcing the importance of values. According to age-group role playing can be conducted. the process of teaching values by role playing revolve around -(a) acting out the story ,(b) depicting certain values , (c) miming, (d) reporting involving the process of seeing, judging, acting and internalizing. Reflection through which of attitude change and growth in values takes place in reflecting is the crucial part of role playing. The art of conducting role playing and using them particularly for younger students requires orientation and practice. (NCERT, 2000).

\section{STORYTELLING :-}

Story telling process is being used to teach children from the ancient time. Through story telling , the narratives, the morals ,the incidents of stories plays a vital role for shaping ones mindset. This mindset is the basic unit of shaping a personality. The understanding of stories and examples makes a bed of morality which is responsible for the behaviour of a person-values gets deep-rooted in this way. Not only from moral stories, the life of a great man, his sayings ,his works reflects on tender mind . the study of religious stories highlighting the essential of all religions as basic teachings of all great religions of the world are the same.the fables and parables of any culture must bear some cult knowledge where values are always highlighted. The explanation of such stories by elders can be most effective particularly in the junior classes. (Mondal ,2017)

\section{GROUPWORIS :-}

Many values can be learned concurrently through group work. Improvement of fundamental values like love, tolerance , cooperation, peaceful coexistence ,mutual respect is important. By working in groups, students learn the value of each others sincere efforts, joy of doing one's best for the good of the whole group ( Rai,2014 ).Group activity may be like group discussion, group singing, group playing etc.

\section{REFLECTIVE PRACTICE :-}

A key implication for value education is allowing time for reflection and value clarification. If students are given time and space for thinking back on their experiences ,they can then begin to see what is important to them, where mistakes are being made, where things can be improved and so on .It is often said that action without reflection is just busyness. The real benefit of reflection is to be able to things in new light . The ability to effect change in one's attitude is perhaps the greatest strength of reflective practice.(NCERT ,2000).

\section{The STAGE SPECIFIC FOCUS FOR VALUE INCULCATION AMONG CHILDREN are-}

\section{- PRE-PRIMARYAND PRIMARYSTAGE:}

During this stage child is like a clay model . Training , guidance and helping is required in every steps of this stage among children. In this stage they are very active, curious ,attentive, sensitive .They loves to enjoy stories, games, group activities repetition, rhythm, dramatisation. Value inculcation among them in this stage with their loving activities deep-roots the values in their behaviour - moulds them . In this way their confidence also builds up and they learns about sharing and caring.

\section{- SECONDARYSTAGE:}

During this stage children begin to grasp abstract thoughts , thinks rationally, able to do more complicated things. As school is a miniature of society so children from multiple settings - religious , cultural, regional backgrounds comes to get educated. In this way, interacting with peer-groups positive attitude and appreciation of cultural diversity gets deep-rooted in their behaviour. They becomes sensitized. This internalizes and reflects their moral reasoning .

Value is woven among students of a school by the total educational programme of school and the school atmosphere .The books, School activities, methods of teaching ,discipline ,total behaviours of teachers, non-teachings and pupils effects to mould values and shaping behaviours of children. The school atmosphere is surged with positive values to imbibe and internalize. Through conscious attempt, proper 
planning and integration and harmony within self and others around builds the philosophy of school to internalise positive dispositions and values among children. Experiences and opportunities must be given to internalise such attitudes and values, which is sustainable.

\section{REFERENCES :-}

1. NCERT ,2000. Education for values in school :A framework ,NCERT ,NEW DELHI

2. Mondal , B.C., 2017 .journal of social sciences DOI : 10.3844/JSSP.2017.

3. Goel,A .and Goel S.L., 2008.Human Values :Principles and Practice. 